\title{
Geschichte aus der Weihnachtszeit
}

Es war einmal ein nasser, kalter Abend in einer grauen Grossstadt im Norden.

Und wieder war es die Weihnachtszeit mit dem typischen windigen Schneeregen. Die Schaufenster der Kaufhäuser waren grell erleuchtet und üppig dekoriert.

In diesen Fensterauslagen gab es viele verlockende Geschenke dargeboten zum Kauf. Dort sass auch ein kleiner hellblauer Plüschbär verloren zwischen den «richtigen» Bären. Diese Teddies aus flauschigem Fell waren so hübsch braun, weiss, schwarz - wie echte. Nur das hellblaue Bärchen mit roten Füssen wollte nicht so recht dort hineinpassen

Dann kam der Tag, an dem alle Geschenke und Weihnachtseinkäufe erledigt waren. Die Dekorationen waren jetzt sinnlos und wurden abgeräumt, die Plüschbären waren verkauft.

Aber dort in der Mitte der riesigen Fensterauslage blieb der kleine Blaubär lange alleine sitzen. Niemand wollte ein hellblaues Bärchen mit roten Füssen, und er würde nun fortgeräumt werden.

Der Winterregen behinderte zwar die Sicht durch die Scheiben, aber der Blaubär war jetzt verschwunden. Es war kurz nach Weihnachten, das Spielzeug war überflüssig, der Bär war jetzt Ausschuss. Die Angestellten warfen die unverkäufliche, zur Rückgabe bereite Ware in den Container.

Eine junge Frau hatte das Bärchen jeden Tag betrachtet und verstand das Zeichen. Die Zeit, Freude zu bereiten, war nicht vorbei, denn die Moral von der Geschicht:

Auch etwas Fremdes zaubert oft ein Lächeln ins Gesicht. Denn wer einsam ist und allein, nimmt es auf - wie einen Sonnenschein.

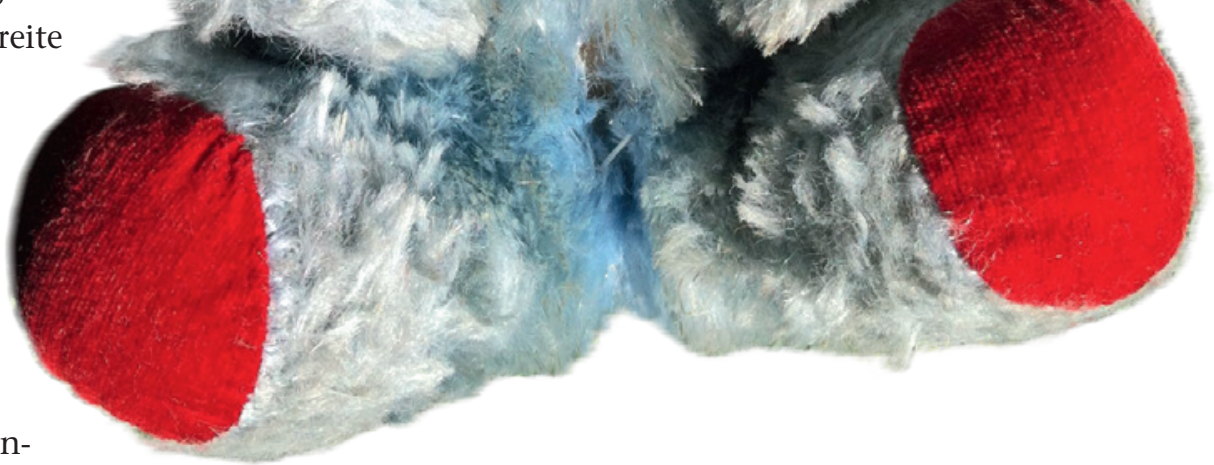

\section{Harriet Keller-Wossidlo}

